\title{
Pengaruh Kecukupan Modal dan Penyaluran Kredit Pada Profitabilitas Dengan Risiko Kredit Sebagai Pemoderasi
}

\author{
Sinta Arya Udayani ${ }^{1}$ \\ I Gde Ary Wirajaya ${ }^{2}$ \\ ${ }^{1,2}$ Fakultas Ekonomi dan Bisnis Universitas Udayana (Unud), Bali, Indonesia \\ e-mail: sintaaryaudayani@gmail.com
}

\begin{abstract}
ABSTRAK
Tujuan penelitian ini untuk mengetahui dan mendapatkan bukti empiris mengenai pengaruh kecukupan modal dan penyaluran kredit pada profitabilitas dengan risiko kredit sebagai pemoderasi. Penelitian ini dilakukan pada Bank Umum Swasta Nasional Devisa yang terdaftar di Bursa Efek Indonesia tahun 2013-2017. Sampel yang diambil sebanyak 17 perusahaan dengan jumlah sampel amatan penelitian sebanyak 85 dalam 5 tahun, melalui metode non probability dengan teknik purposive sampling. Metode pengumpulan data dalam penelitian ini adalah metode dokumentasi. Teknik analisis data yang digunakan adalah Moderated Regression Analysis. Berdasarkan hasil analisis diketahui bahwa bank yang memiliki tingkat kecukupan modal yang tinggi namun jika memiliki tingkat risiko kredit yang tinggi akan menurunkan profitabilitas dan bank yang memiliki tingkat penyaluran kredit yang tinggi namun jika memiliki tingkat risiko kredit yang tinggi akan menurunkan profitabilitas bank.
\end{abstract}

Kata kunci : Kecukupan modal, penyaluran kredit, risiko kredit, profitabilitas

\begin{abstract}
The purpose of this study is to find out and obtain empirical evidence about the effect of capital adequacy and lending on profitability with credit risk as moderating. This research was conducted at the Foreign Exchange National Private Commercial Bank listed on the Indonesia Stock Exchange in 2013-2017. Samples taken were 17 companies with a total sample of 85 research observations in 5 years, through non-probability methods with purposive sampling technique. The method of data collection in this study is the documentation method. The data analysis technique used is Moderated Regression Analysis. Based on the results of the analysis it is known that banks that have a high level of capital adequacy but if they have a high level of credit risk will reduce profitability and banks that have a high level of credit distribution but if they have a high level of credit risk will reduce bank profitability.

Keywords: Capital adequacy, credit distribution, credit risk, profitability
\end{abstract}

\section{PENDAHULUAN}

Profitabilitas adalah kemampuan perusahaan untuk menghasilkan laba dalam periode tertentu (Riaz, 2013). Profitabilitas juga memiliki arti penting dalam mempertahankan kelangsungan hidup jangka panjang bagi suatu badan usaha, hal ini dikarenakan profitabilitas menunjukkan apakah badan usaha tersebut 
mempunyai prospek yang baik di masa yang akan datang (Haneef, et al., 2012). Pada sektor perbankan, profitabilitas digunakan untuk mengukur kinerja bank tersebut. Profitabilitas menjadi penting bagi bank karena profitabilitas merupakan pertahanan yang utama dalam bank terhadap kerugian yang tidak terduga, seperti memperkuat posisi modal dan meningkatkan profitabilitas masa depan.

Tingginya tingkat profitabilitas suatu bank dapat menunjukkan bahwa sebagian besar kinerja bank tersebut sudah sangat baik dalam mengelola keuangannya, karena diasumsikan bahwa bank telah beroperasi secara efektif dan efisien serta memungkinkan bank untuk memperluas usahanya. Penting bagi suatu bank untuk menjaga profitabilitasnya tetap stabil bahkan meningkat untuk memenuhi kewajiban kepada pemegang saham, meningkatkan daya tarik investor dalam menanamkan modal dan meningkatkan kepercayaan masyarakat untuk menyimpan dana simpanannya pada bank (Agustiningrum, 2013). Tingkat profitabilitas dalam penelitian ini diukur dengan rasio Return on Asset (ROA), karena ROA mengukur kemampuan manajemen bank dalam memperoleh keuntungan (laba) secara keseluruhan (Dendawijaya, 2009:119). ROA merefleksikan seberapa banyak perusahaan telah memperoleh hasil atas sumber daya keuangan yang ditanamkan pada perusahaann khususnya pada perusahaanperbankan BUSN Devisa.

Pemilihan penelitian pada BUSN Devisa yang terdaftar di BEI dikarenakan BUSN Devisa merupakan bank yang dalam kegiatan operasionalnya tidak melibatkan pemerintah seperti Bank Persero, sehingga BUSN Devisa benarbenar bersaing ketat dalam mencapai tingkat profitabilitasnya. Sehingga penting 
bagi BUSN Devisa untuk terus meningkatkan profitabilitas. BUSN Devisa juga memiliki ruang lingkup luas, karena dapat melaksanakan transaksi ke luar negeri atau yang berhubungan dengan mata uang asing secara keseluruhan. Berikut gambaran mengenai tingkat profitabilitas Bank Umum Swasta Nasional (BUSN) Devisa tahun 2013-2017 dapat dilihat pada Gambar 1.

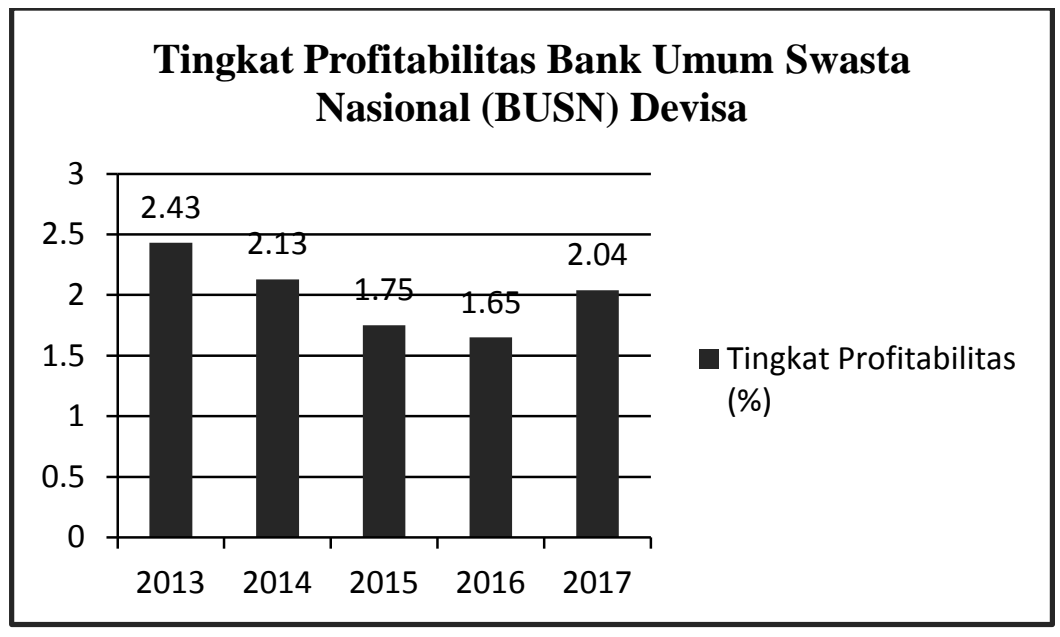

\section{Gambar 1. Grafik Tingkat Profitabilitas Bank Umum Swasta Nasional} Devisa Tahun 2013-2017

Sumber: Statistik Perbankan Indonesia (www.ojk.go.id), 2018

Gambar 1. menunjukkan bahwa tingkat profitabilitas BUSN selama tahun 2013-2016 mengalami penurunan, sedangkan pada tahun 2017 mulai mengalami peningkatan. Tingkat profitabilitas terendah terjadi pada tahun 2016 yaitu sebesar 1,65\% dan tingkat profitabilitas tertinggi terjadi pada tahun 2013 sebesar 2,43\%. Hal ini menunjukkan bahwa BUSN cenderung masih mengalami kesulitan untuk menjaga pertumbuhan tingkat profitabilitas setiap tahunnya. Berdasarkan fenomena di atas, tingkat profitabilitas yang rendah dapat dipengaruhi oleh beberapa faktor yang juga dapat digunakan dalam penilaian kinerja bank, seperti kecukupan modal dan penyaluran kredit. 
Penelitian ini menggunakan teori Pecking Order Theory yang menyatakan bahwa perusahaan akan mengutamakan pendanaan dari dalam perusahaan (internal financing) lebih dulu dari sumber pendanaan dari luar perusahaan (external financing). Berdasarkan teori tersebut, salah satu faktor penting agar suatu perusahaan mampu beroperasi adalah kecukupan modal yang digunakan sebagai pendanaan dari dalam perusahaan. Modal merupakan salah satu faktor yang berperan penting terhadap kinerja perusahaan. Modal yang dimiliki oleh bank berfungsi untuk menanggung risiko dan kerugian yang dialami oleh bank, sehingga bank dituntut untuk memiliki modal yang cukup sehingga mampu untuk menanggung risiko dan kerugian tersebut. Kecukupan modal perbankan dapat dilihat dari tingkat Capital Adequacy Ratio (CAR). CAR merupakan rasio permodalan yang menunjukkan kemampuan bank dalam menyediakan dana untuk keperluan pengembangan usaha dan menampung risiko kerugian dana yang diakibatkan oleh kegiatan operasi bank (Ali, 2004). CAR menunjukkan sejauh mana penurunan aset bank masih dapat ditutup oleh modal bank yang tersedia. Semakin tinggi rasio kecukupan modal, maka semakin kuat kemampuan bank tersebut untuk menanggung risiko dari setiap kredit dan mampu membiayai operasi bank, sehingga akan memberikan kontribusi yang cukup besar bagi profitabilitas (Suhardjono dan Kuncoro, 2002:573).

Dipertegas dengan teori abstinenceyang menyatakan bahwa dalam dunia perbankan, kredit yang diberikan oleh pihak bank kepada masyarakat tentunya akan menghasilkan pendapatan bunga yang akan mempengaruhi jumlah laba suatu perusahaan perbankan. Berdasarkan teori tersebut, profitabilitas juga 
dipengaruhi oleh aktivitas penyaluran kredit. Melalui penyaluran kredit, bank akan memperoleh keuntungan yang bersumber dari pendapatan bunga. Bank akan memberikan kredit kepada nasabah jika ia mampu mengembalikan pinjaman yang diterimanya sesuai dengan jangka waktu dan syarat-syarat yang ditetapkan. Penyaluran kredit yang dilakukan oleh bank dapat dilihat melalui tingkat Loan to Deposit Ratio (LDR). Menurut Riyadi (2015:199) rasio LDR adalah perbandingan total kredit terhadap Dana Pihak Ketiga (DPK). Total kredit yang dimaksud adalah kredit yang diberikan kepada pihak ketiga (tidak termasuk kredit kepada bank lain). DPK dalam hal ini yakni tabungan, giro dan deposito. Semakin besarnya jumlah kredit yang diberikan, maka laba yang diperoleh juga akan semakin besar. Hal ini dikarenakan penyaluran kredit akan menghasilkan pendapatan bunga bagi bank (Putra dan Suardikha, 2015). Apabila bank dapat menyalurkan seluruh dana yang dihimpun maka bank tersebut akan memperoleh keuntungan yang besar yang akan berdampak pada peningkatan profitabilitas.

Penelitian tentang pengaruh kecukupan modal dan penyaluran kredit terhadap profitabilitas telah dilakukan oleh beberapa peneliti sebelumnya. Mubarok (2010) menunjukkan bahwa kecukupan modal berpengaruh positif terhadap profitabilitas bank. Sedangkan penelitian yang dilakukan oleh Negara (2014) menunjukkan hasil bahwa tingkat kecukupan modal tidak berpengaruh terhadap profitabilitas. Demikian juga dengan penelitian yang dilakukan Alhaq (2012), menunjukkan hasil bahwa kecukupan modal tidak berpengaruh terhadap profitabilitas. Kecukupan modal menjadi tidak berpengaruh terhadap profitabilitas karena sudah memiliki struktur permodalan yang kuat. 
Penelitian yang dilakukan oleh Alhaq, dkk. (2012) menunjukkan penyaluran kredit berpengaruh positif terhadap profitabilitas. Sejalan dengan penelitian yang dilakukan oleh Septiarini dan Ramantha (2014) menunjukkan penyaluran kredit berpengaruh positif terhadap profitabilitas. Indrayani, dkk. (2016) juga mengatakan bahwa jumlah kredit yang disalurkan diproksikan denganLoan to Deposit Ratio (LDR) berpengaruh positif terhadap profitabilitas. Akan tetapi, penelitian tersebut bertolak belakang dengan penelitian yang dilakukan Wibisono (2013) yang menunjukkan hasil Loan to Deposit Ratio (LDR) memiliki pengaruh negatif pada profitabilitas.

Berdasarkan hasil penelitian sebelumnya yang disebutkan diatas terjadi hasil yang tidak konsisten mengenai pengaruh antara kecukupan modaldan penyaluran kredit terhadap profitabilitas, sehingga untuk menyelesaikan perbedaan hasil dari penelitian sebelumnya digunakan pendekatan kontijensi. Pendekatan kontijensi memberi peluang kepada variabel lain untuk menjadi moderating yang dapat mempengaruhi profitabilitas. Dalam penelitian ini, peneliti mencoba menggunakan risiko kredit sebagai variabel moderasi.Risiko kredit digunakan sebagai variabel moderasi karena pada penelitian Nusantara (2009) risiko kredit sebagai variabel independen menunjukkan hasil yang tidak berpengaruh pada profitabilitas, namun pada dasarnya risiko kredit mempunyai pengaruh yang dapat menurunkan profitabilitas karena kemungkinan dari tidak tertagihnya jumlah kredit kepada nasabah semakin besar (Myrna, 2013). Berdasarkan hal tersebut diduga risiko kreditmemiliki pengaruh yang tidak 
langsung pada profitabilitas,sehingga penelitian ini menempatkan risiko kredit sebagai variabel moderasi.

Salah satu faktor internal yang dapat mempengaruhi kecukupan modal dan penyaluran kredit adalah risiko kredit (Novita, 2016). Tingkat risiko kredit perbankan dapat diukur dengan rasio Non Performing Loan (NPL). Menurut Apriani (2011) dalam Honora, dkk. (2017) NPL merupakan suatu keadaan dimana nasabah sudah tidak sanggup membayar sebagian atau seluruh kewajibannya kepada bank seperti yang dijanjikan. Lembaga keuangan yang memiliki tingkat NPL yang tinggi menjadi lebih beresiko mengalami kerugian dalam pemberian kredit (Tracey, 2011), sehingga semakin tinggi NPL maka resiko kredit yang ditanggung juga semakin besar. Semakin tinggi resiko kredit maka semakin tinggi kecenderungan bank mengalami krisis keuangan (Kalopo, et al., 2012). Hal ini menyebabkan lembaga keuangan harus berhati-hati dalam memberikan kredit.

Banyaknya kredit bermasalah mengakibatkan semakin berkurangnya dana atau modal yang dihimpun sehingga dapat menurunkan kemampuan bank dalam menyalurkan kredit. Hal ini dapat mengakibatkan turunnya kepercayaan nasabah yang dapat menurunkan profitabilitas (Dewi dan Budiasih, 2016). Akibat tingginya NPL, perbankan harus menyediakan pencadangan yang lebih besar, sehingga modal bank juga akan ikut terkikis. Besarnya NPL menjadi salah satu penyebab sulitnya perbankan dalam menyalurkan kredit (Sentausa, 2009). Berdasarkan alasan tersebut, maka risiko kredit diduga akan memperlemah pengaruh kecukupan modal dan penyaluran kredit pada profitabilitas. 
Bank Indonesia dalam Surat Edaran Bank Indonesia Nomor 06/23/DPNP tanggal 31 Mei 2014 mengemukakan terdapat tiga rasio yang dapat digunakan sebagai parameter dari profitabilitas bank yakni Return on Asset (ROA), Return on Equity (ROE) dan Net Interest Margin (NIM). ROA dianggap mampu mewakili parameter lainnya, sedangkan ROE hanya menggambarkan kemampuan perbankan dalam memperoleh keuntungan berdasarkan pemanfaatan modal yang telah ditanamkan dan NIM menggambarkan perolehan keuntungan hanya berdasarkan aktiva produktifnya saja. Semakin besar persentase yang ditunjukkan oleh ROA menandakan bahwa kemampuan manajemen semakin optimal dalam peningkatan produktivitas (Dendawijaya, 2005).

Tingkat profitabilitas dalam penelitian ini diukur dengan rasio Return on Asset (ROA) karena ROA menghitung kinerja keuangan perusahaan dengan membandingkan laba bersih yang diperoleh perusahaan dengan total aset yang dimiliki perusahaan. Menurut Dendawijaya (2009: 119) menyatakan bahwa rasio ROA digunakan untuk mengukur kemampuan manajemen bank dalam memperoleh keuntungan (laba) secara keseluruhan. ROA merefleksikan seberapa banyak perusahaan telah memperoleh hasil atas sumber daya keuangan yang ditanamkan pada perusahaan. Semakin besar ROA suatu bank semakin besar pula tingkat keuntungan yang diperoleh bank tersebut dan semakin baik pula posisi bank tersebut dari sisi penggunaan aktiva (Hantono, 2017).

Modal yang dimiliki oleh bank berfungsi untuk menanggung risiko dan kerugian yang dialami oleh bank, sehingga bank dituntut untuk memiliki modal yang cukup sehingga mampu untuk menanggung risiko dan kerugian tersebut. 
Penelitian tentang pengaruh kecukupan modal dan penyaluran kredit terhadap profitabilitas telah dilakukan oleh beberapa peneliti sebelumnya. Mubarok (2010) menunjukkan bahwa kecukupan modal berpengaruh positif terhadap profitabilitas bank. Sedangkan penelitian yang dilakukan oleh Negara (2014) menunjukkan hasil bahwa tingkat kecukupan modal tidak berpengaruh terhadap profitabilitas. Demikian juga dengan penelitian yang dilakukan Alhaq (2012), menunjukkan hasil bahwa kecukupan modal tidak berpengaruh terhadap profitabilitas.

Semakin tinggi rasio kecukupan modal, maka semakin kuat kemampuan bank tersebut untuk menanggung risiko dari setiap kredit dan mampu membiayai operasi bank, sehingga akan memberikan kontribusi yang cukup besar bagi profitabilitas (Suhardjono dan Kuncoro, 2002:573).

Risiko kredit suatu bank ditunjukkan dengan tingkat Non Performing Loan (NPL). Semakin tinggi tingkat risiko kredit suatu bank akan menyebabkan bank harus mengeluarkan biaya untuk menanggung risiko kredit tersebut. Pecking Order Theory menyatakan bahwa perusahaan akan mengutamakan pendanaan dari dalam perusahaan (internal financing) lebih dulu dari sumber pendanaan dari luar perusahaan (external financing). Biaya yang digunakan untuk menanggung risiko kredit dapat berasal dari modal bank, hal ini dapat menyebabkan modal bank menjadi terkikis dan menurunkan tingkat Capital Adequacy Ratio (CAR) pada bank yang akan berdampak pada penurunan profitabilitas karena hilangnya kepercayaan nasabah terhadap bank.

Penelitian yang dilakukan Utomo (2008) menyatakan bahwa risiko kredit memperlemah pengaruh kecukupan modal pada profitabilitas. Demikian juga 
dengan penelitian yang dilakukan oleh Suardita (2015) yang menunjukkan hasil bahwa risiko kredit memperlemah pengaruh kecukupan modal pada profitabilitas. Akan tetapi, penelitian tersebut bertolak belakang dengan penelitian yang dilakukan oleh Purba (2018) yang menunjukkan hasil bahwa risiko kredit tidak terbukti memperlemah hubungan kecukupan modal pada profitabilitas.

Tingkat rasio CAR yang tinggi menunjukkan bahwa bank tersebut mampu mengelola aspek modalnya sehingga kepercayaan masyarakat akan bertambah dan tingkat profitabilitas akan meningkat. Apabila rasio NPL mengalami peningkatan akan menyebabkan CAR mengalami penurunan, hal ini dikarenakan dana yang seharusnya menjadi modal digunakan untuk menutupi tingginya rasio NPL. Hal ini akan berakibat pada penurunan tingkat profitabilitas. Berdasarkan uraian tersebut, maka dapat dirumuskan hipotesis sebagai berikut :

$\mathrm{H}_{1}$ : Risiko kredit memperlemah pengaruh positif kecukupan modal pada profitabilitas.

Aktivitas utama suatu bank adalah menyalurkan kredit kepada debitur. Melalui penyaluran kredit, bank akan memperoleh keuntungan yang bersumber dari pendapatan bunga. Bank akan memberikan kredit kepada nasabah jika ia mampu mengembalikan pinjaman yang diterimanya sesuai dengan jangka waktu dan syarat-syarat yang ditetapkan.

Alhaq, dkk. (2012) menunjukkan penyaluran kredit berpengaruh positif terhadap profitabilitas. Sejalan dengan penelitian yang dilakukan oleh Septiarini dan Ramantha (2014) menunjukkan penyaluran kredit berpengaruh positif terhadap profitabilitas. Indrayani, dkk. (2016) juga mengatakan bahwa jumlah kredit yang disalurkan diproksikan dengan Loan to Deposit Ratio (LDR) 
berpengaruh positif terhadap profitabilitas. Akan tetapi, penelitian tersebut bertolak belakang dengan penelitian yang dilakukan Wibisono (2013) yang menunjukkan hasil Loan to Deposit Ratio (LDR) memiliki pengaruh negatif pada profitabilitas.

Semakin besarnya jumlah kredit yang diberikan, maka laba yang diperoleh juga akan semakin besar. Hal ini dikarenakan penyaluran kredit akan menghasilkan pendapatan bunga bagi bank (Putra dan Suardikha, 2015). Apabila bank dapat menyalurkan seluruh dana yang dihimpun maka bank tersebut akan memperoleh keuntungan yang besar yang akan berdampak pada peningkatan profitabilitas.

Semakin banyak kredit yang disalurkan, maka semakin besar resiko kredit yang dihadapi oleh bank. Resiko tersebut berupa tidak lancarnya pembayaran kredit atau kredit bermasalah yang dapat diukur dengan rasio Non Performing Loan (NPL). Risiko kredit yang tinggi akan menyebabkan bank mengurangi penyaluran kredit, hal ini dikarenakan dana yang telah disalurkan tidak kembali. Teori abstinence menyatakan bahwa dalam dunia perbankan, kredit yang diberikan oleh pihak bank kepada masyarakat tentunya akan menghasilkan pendapatan bunga yang akan mempengaruhi jumlah laba suatu perusahaan perbankan. Jika bank tidak optimal menyalurkan dana dalam bentuk kredit maka pendapatan bunga yang seharusnya diterima menjadi berkurang (Trisna, 2017).

Penelitian yang dilakukan oleh Oktaviani dan Yusuf (2014) menyatakan bahwa risiko kredit memperlemah pengaruh penyaluran kredit pada profitabilitas. Demikian juga dengan penelitian yang dilakukan Dewi (2018) menyatakan bahwa 
risiko kredit memperlemah pengaruh penyaluran kredit pada profitabilitas. Akan tetapi, penelitian tersebut bertolak belakang dengan penelitian yang dilakukan oleh Warnayanti dan Dewi (2017) yang menunjukkan hasil bahwa risiko kredit tidak mampu memoderasi penyaluran kredit.

Semakin banyak kredit yang disalurkan menunjukkan bahwa bank tersebut memiliki kemampuan yang bagus dalam menyalurkan dana yang dihimpun dari masyarakat ke dalam bentuk kredit. Peningkatan rasio penyaluran kredit dapat meningkatkan fungsi bank sebagai lembaga perantara sehingga kepercayaan masyarakat akan bertambah dan tingkat profitabilitas akan meningkat. Kelancaran pengembalian kredit oleh nasabah menjadi tolak ukur bahwa bank dapat mengelola dana dengan baik.

$\mathrm{H}_{2}$ : Risiko kredit memperlemah pengaruh positif penyaluran kredit pada profitabilitas.

\section{METODE PENELITIAN}

Penelitian ini dilakukan pada Bursa Efek Indonesia (BEI) yang menyediakan informasi laporan keuangan perusahaan yang dapat diperoleh dengan mengakses situs resmi Bursa Efek Indonesia yaitu www.idx.co.id. Lokasi penelitian ini dipilih karena populasi dalam penelitian ini adalah seluruh Bank Umum Swasta Nasional (BUSN) Devisa yang terdaftar dan mempublikasikan laporan keuangannya di Bursa Efek Indonesia (BEI).

Variabel bebas dalam penelitian ini adalah kecukupan modal $\left(\mathrm{X}_{1}\right)$ dan penyaluran kredit $\left(\mathrm{X}_{2}\right)$.Variabel terikat dalam penelitian ini adalah profitabilitas (Y).Variabel moderasi dalam penelitian ini adalah risiko kredit (Z). 
Besarnya CAR diperoleh dari laporan tahunan bank yang digunakan sebagai sampel. Rumus CAR adalah sebagai berikut (Herli, 2013:135):

$\mathrm{X}_{1}=\mathrm{CAR}=\frac{\text { Modal (inti }+ \text { pelengkap) }}{\text { Aktiva Tertimbang Menurut Resiko }} \times 100 \%$

Rumus LDR adalah sebagai berikut (Dendawijaya, 2005:116):

$\mathrm{X}_{2}=\mathrm{LDR}=\frac{\text { Jumlah Kredit yang Diberikan }}{\text { Dana Pihak Ketiga }} \times 100 \%$

Menurut Surat Edaran Bank Indonesia Nomor 6/23/DPNP tanggal 31 Mei 2004, NPL dapat dirumuskan sebagai berikut:

$\mathrm{Z}=\mathrm{NPL}=\frac{\text { Kredit Bermasalah }}{\text { Total Kredit }} \times 100 \%$

Besarnya ROA diperoleh dari laporan tahunan bank yang digunakan sebagai sampel. ROA dapat dirumuskan sebagai berikut (Wiagustini, 2010:81):

$\mathrm{Y}=\mathrm{ROA}=\frac{\text { Laba Bersih }}{\text { Total Aset }} \times 100 \%$

Populasi dalam penelitian ini adalah seluruh Bank Umum Swasta Nasional (BUSN) Devisa yang terdaftar di BEI dalam kurun waktu 2013-2017 dan masih aktif beroperasi secara normal.Sampel akan diambil dari populasi tersebut dengan pendekatan non probabilitas menggunakan teknik purposive sampling.

Pengujian hipotesis dilakukan dengan menggunakan analisis regresi moderasi atau Moderated Regression Analysis (MRA). Model regresi moderasi penelitian ini ditunjukkan oleh persamaan berikut :

$\mathrm{Y}=\alpha+\beta_{1} \mathrm{X}_{1}+\beta_{2} \mathrm{X}_{2}+\beta_{3} \mathrm{Z}+\beta_{4} \mathrm{X}_{1} * \mathrm{Z}+\beta_{5} \mathrm{X}_{2} * \mathrm{Z}+\mathrm{e}$

Keterangan :

Y

$\mathrm{X}_{1}$

$\mathrm{X}_{2}$

$\mathrm{Z}$

$\mathrm{X}_{1} * \mathrm{Z}$
$=$ Profitabilitas

$=$ Kecukupan Modal

$=$ Penyaluran Kredit

$=$ Risiko Kredit

$=$ Interaksi antara kecukupan modal dan risiko kredit 


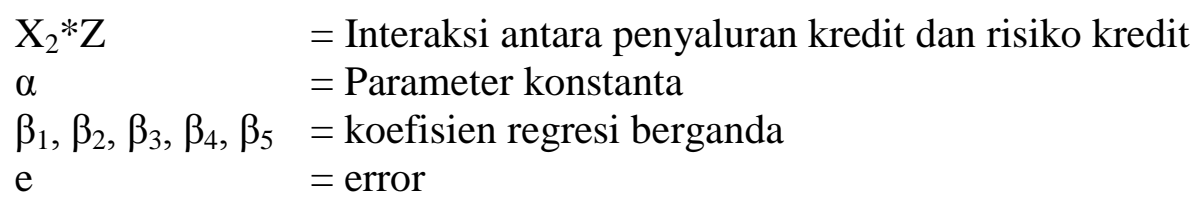

\section{HASIL DAN PEMBAHASAN}

Populasi data sejak tahun 2013 sampai dengan 2017 terdapat 23 perusahaan bank umum milik swasta nasional devisa yang terdaftar di Bursa efek Indonesia secara berturut-turut dari tahun 2013 sampai dengan tahun 2017 yang diperoleh dari website www.idx.co.id. Perusahaan yang dipilih sebagai sampel merupakan perusahaan yang diseleksi kembali sesuai dengan kriteria purposive sampling yang telah ditetapkan sebelumnya.Hasil analisis sampel dengan menggunakan purposive sampling disajikan pada Tabel 1.

\section{Tabel 1.}

Proses Seleksi Sampel dengan Purposive Sampling

\begin{tabular}{|c|c|}
\hline Kriteria & Jumlah \\
\hline $\begin{array}{l}\text { BUSN Devisa yang terdaftar di BEI pada tahun } \\
\text { 2013-2017 }\end{array}$ & 23 \\
\hline $\begin{array}{l}\text { BUSN Devisa yang mengalami kerugian selama } \\
\text { periode penelitian }\end{array}$ & (6) \\
\hline $\begin{array}{l}\text { Jumlah perusahaan yang digunakan sebagai } \\
\text { sampel }\end{array}$ & 17 \\
\hline $\begin{array}{l}\text { Jumlah sampel (17 perusahaan } \times 5 \text { tahun } \\
\text { pengamatan) }\end{array}$ & 85 \\
\hline
\end{tabular}
Sumber: Data diolah, 2018

Statistik deskriptif disajikan untuk memberikan informasi mengenai karakteristik variable - variable penelitian, yaitu jumlah sampel, nilai maksimum, nilai minimum, nilai rata-rata dan standar deviasi. Hasil statistic deskriptif penelitian ini dapat dilihat pada Tabel 2 berikut. 
Tabel 2.

Hasil Uji Statistik Deskriptif

\begin{tabular}{lccccc}
\hline & $\mathrm{N}$ & Minimum & Maximum & Mean & Std. Deviation \\
\hline CAR & 85 & 10,25 & 35,12 & 19,38 & 5,30 \\
LDR & 85 & 50,61 & 122,18 & 85,49 & 13,16 \\
NPL & 85 &, 21 & 8,54 & 2,33 & 1,36 \\
ROA & 85 &, 13 & 3,90 & 1,22 &, 74 \\
Valid N (listwise) & 85 & & & & \\
\hline
\end{tabular}

Sumber: Data diolah, 2018

Berdasarkan hasil uji statistik deskriptif pada Tabel 2 maka hasil statistik deskriptif masing-masing dapat dijelaskan variabel kecukupan modal yang diproksikan dengan Capital Adequacy Ratio (CAR) memiliki sampel dalam penelitian yang berjumlah 85. Variabel kecukupan modal memiliki nilai minimum sebesar 10,25 yang berarti nilai terendah dari variabel kecukupan modal adalah sebesar 10,25 persen yaitu kecukupan modal dari Bank Mayapada (MAYA). Nilai maksimum kecukupan modal adalah sebesar 35,12 yang berarti nilai tertinggi variabel kecukupan modal dari sampel penelitian adalah sebesar 35,12 persen yaitu kecukupan modal dari Bank Mestika Dharma (BBMD). Mean dari kecukupan modal adalah 19,38 artinya bahwa rata-rata kecukupan modal pada 85 sampel Bank Umum Swasta Nasional (BUSN) Devisa pada tahun 20132017 adalah 19,38 persen. Nilai rata-rata variabel kecukupan modal lebih mendekati nilai minimumnya, hal ini berarti rata-rata kecukupan modal pada BUSN Devisa cenderung rendah. Standar deviasi sebesar 5,30 artinya terjadi penyimpangan nilai kecukupan modal terhadap nilai rata-ratanya sebesar 5,30 persen.

Variabel penyaluran kredit yang diproksikan dengan Loan to Deposit Ratio (LDR) memiliki sampel dalam penelitian yang berjumlah 85. Variabel penyaluran kredit memiliki nilai minimum sebesar 50,61 yang berarti nilai 
terendah dari variabel penyaluran kredit adalah sebesar 50,61 persen yaitu penyaluran kredit dari Bank Capital Indonesia (BACA). Nilai maksimum penyaluran kredit adalah sebesar 122,18 yang berarti nilai tertinggi variabel penyaluran kredit dari sampel penelitian adalah sebesar 122,18 persen yaitu penyaluran kredit dari Bank Danamon (BDMN). Mean dari penyaluran kredit adalah 85,49 artinya bahwa rata-rata penyaluran kredit pada 85 sampel Bank Umum Swasta Nasional (BUSN) Devisa pada tahun 2013-2017 adalah 85,49 persen. Nilai rata-rata variabel penyaluran kredit lebih mendekati nilai minimumnya, hal ini berarti rata-rata penyaluran kredit pada BUSN Devisa cenderung rendah. Standar deviasi sebesar 13,16 artinya terjadi penyimpangan nilai penyaluran kredit terhadap nilai rata-ratanya sebesar 13,16 persen.

Variabel risiko kredit yang diproksikan dengan Non Performing Loan (NPL) memiliki sampel dalam penelitian yang berjumlah 85. Variabel risiko kredit memiliki nilai minimum sebesar 0,21 yang berarti nilai terendah dari variabel risiko kredit adalah sebesar 0,21 persen yaitu risiko kredit dari Bank Bumi Arta (BNBA). Nilai maksimum risiko kredit adalah sebesar 8,54 yang berarti nilai tertinggi variabel risiko kredit dari sampel penelitian adalah sebesar 8,54 persen yaitu risiko kredit dari Bank Bukopin (BBKP). Mean dari risiko kredit adalah 2,33 artinya bahwa rata-rata risiko kredit pada 85 sampel Bank Umum Swasta Nasional (BUSN) Devisa pada tahun 2013-2017 adalah 2,33 persen. Nilai rata-rata variabel risiko kredit lebih mendekati nilai minimumnya, hal ini berarti rata-rata risiko kredit pada BUSN Devisa cenderung rendah. Standar deviasi 
sebesar 1,36 artinya terjadi penyimpangan nilai penyaluran kredit terhadap nilai rata-ratanya sebesar 1,36 persen.

Variabel profitabilitas yang diproksikan dengan Return on Assets (ROA) memiliki sampel dalam penelitian yang berjumlah 85. Variabel profitabilitas memiliki nilai minimum sebesar 0,13 yang berarti nilai terendah dari variabel profitabilitas adalah sebesar 0,13 persen yaitu profitabilitas dari Bank Bukopin (BBKP). Nilai maksimum profitabilitas adalah sebesar 3,90 yang berarti nilai tertinggi variabel profitabilitas dari sampel penelitian adalah sebesar 3,90 persen yaitu profitabilitas dari Bank Mestika Dharma (BBMD). Mean dari profitabilitas adalah 1,22 artinya bahwa rata-rata profitabilitas pada 85 sampel Bank Umum Swasta Nasional (BUSN) Devisa pada tahun 2013-2017 adalah 1,22 persen. Nilai rata-rata variabel profitabilitas lebih mendekati nilai minimumnya, hal ini berarti rata-rata profitabilitas pada BUSN Devisa cenderung rendah. Standar deviasi sebesar 0,74 artinya terjadi penyimpangan nilai profitabilitas terhadap nilai rataratanya sebesar 0,74 persen.

Pengujian data dalam penelitian ini menggunakan teknik Moderated Regression Analysis (MRA). Perhitungan koefisien MRA dilakukan dengan analisis regresi melalui software SPSS 18.0 for Windows, diperoleh hasil yang ditunjukan pada Tabel 3 berikut. 
Tabel 3.

Hasil Uji Moderated RegressionAnalysis (MRA)

\begin{tabular}{|c|c|c|c|c|c|}
\hline \multirow[t]{3}{*}{ Model } & \multirow{2}{*}{\multicolumn{2}{|c|}{ Unstandardized Coefficients }} & \multicolumn{3}{|l|}{ Standardized } \\
\hline & & & \multirow{2}{*}{$\begin{array}{c}\text { Coefficients } \\
\text { Beta }\end{array}$} & \multirow[t]{2}{*}{$\mathrm{T}$} & \multirow[t]{2}{*}{ Sig. } \\
\hline & $\mathrm{B}$ & Std. Error & & & \\
\hline 1 (Constant) & 1,26 &, 11 & & 10,90 & ,00 \\
\hline CAR & 00 & ,00 & 01 & 3,46 & ,00 \\
\hline LDR & 01 & ,00 & 24 & 2,20 & ,02 \\
\hline NPL &,- 03 & 00 &,- 05 & $-4,23$ & 00 \\
\hline Interaksi X1.Z &,- 00 & ,00 &,- 03 & $-2,30$ & ,02 \\
\hline Interaksi X2.Z &,- 01 & ,00 & $-1,04$ & $-3,45$ & ,00 \\
\hline R Square & & & & & 0,79 \\
\hline Adjusted R Square & & & & & 0,78 \\
\hline F Statistik & & & & & 768,78 \\
\hline Signifikansi & & & & & 0,00 \\
\hline
\end{tabular}

Berdasarkan hasil analisis Moderated Regression Analysisseperti yang disajikan pada Tabel 3, maka persamaan strukturalnya adalah sebagai berikut :

$$
Y=1,26+0,00 X_{1}+0,01 X_{2^{-}} 0,03 X_{3}-0,00 X_{1} \cdot Z-0,01 X_{2} \cdot Z+e
$$

Koefisien determinasi $\left(\mathrm{R}^{2}\right)$ digunakan untuk mengetahui dan mengukur kemampuan model dalam menerangkan variasi variabel independen. Peneliti menggunakan nilai adjusted $\mathrm{R}^{2}$ pada saat mengevaluasi yang mana model regresi terbaik, karena tidak seperti $\mathrm{R}^{2}$, nilai adjusted $\mathrm{R}^{2}$ dapat naik atau turun apabila satu variabel independen ditambahkan ke dalam model. Hasil uji memberikan hasil dimana diperoleh besarnya adjusted $\mathrm{R}^{2}$ (koefisien determinasi yang telah disesuaikan) pada Tabel 3 adalah 0,78. Ini berarti variasi Profitabilitas dapat dipengaruhi secara signifikan oleh variabel CAR $\left(\mathrm{X}_{1}\right)$, LDR $\left(\mathrm{X}_{2}\right), \mathrm{NPL}(\mathrm{Z})$, interaksi $\mathrm{X}_{1}$.Zdan interaksi $\mathrm{X}_{2} . \mathrm{Z}$ sebesar 78 persen, sedangkan sisanya sebesar 22 persen dijelaskan oleh faktor-faktor lain yang tidak dijelaskan dalam model penelitian. 
Hasil uji F (Ftest) menunjukkan bahwa nilai signifikansi P value 0,00 yang lebih kecil dari $\alpha=0,05$, ini berarti model yang digunakan pada penelitian ini adalah layak. Hasil ini memberikan makna bahwa seluruh variabel independen mampu memprediksi atau menjelaskan fenomena Profitabilitas. Dengan kata lain CAR $\left(\mathrm{X}_{1}\right)$, LDR $\left(\mathrm{X}_{2}\right)$, NPL $(\mathrm{Z})$, interaksi CAR dengan NPLdan interaksi LDR dengan NPLsecara simultan berpengaruh signifikan terhadap Profitabilitas. Hal ini berarti model dapat digunakan untuk analisa lebih lanjut atau dengan kata lain model dapat digunakan untuk memproyeksikan karena hasil goodness of fitnya baik dengan nilai signifikansi $\mathrm{P}$ value 0,00 .

Hasil analisis regresi moderasi menunjukkan bahwa nilai koefisien regresi kecukupan modal (CAR) $\left(\beta_{1}\right)$ positif sebesar 0,00 dengan nilai signifikansi sebesar 0,00 dan nilai koefisien regresi variabel interaksi $X_{1} . Z\left(\beta_{4}\right)$ negatif sebesar -0,00 dengan nilai signifikansi 0,02 , maka hal tersebut menunjukkan adanya hubungan yang tidak searah atau berlawanan karena memiliki nilai koefisien yang berbeda, sehingga dapat disimpulkan bahwa variabel Risiko kredit (NPL) merupakan variabel moderasi yang memperlemah pengaruh kecukupan modal (CAR) pada Profitabilitas.

Hasil analisis Moderated Regression Analysis(MRA) menunjukkan bahwa nilai koefisien regresi penyaluran kredit (LDR) $\left(\beta_{2}\right)$ positif sebesar 0,01 dengan nilai signifikansi sebesar 0,02 dan nilai koefisien regresi variabel interaksi $\mathrm{X}_{2} . \mathrm{Z}$ $\left(\beta_{5}\right)$ negatif sebesar $-0,01$ dengan nilai signifikansi 0,00 , maka hal tersebut menunjukkan adanya hubungan yang tidak searah atau berlawanan karena memiliki nilai koefisien yang berbeda, sehingga dapat disimpulkan bahwa 
variabel Risiko kredit (NPL) merupakan variabel moderasi yang memperlemah pengaruhpenyaluran kredit (LDR) pada Profitabilitas.

Hasil pengujian dengan menggunakan Moderated Regression Analysis (MRA) menunjukkan bahwa koefisien regresi kecukupan modal yang diproksikan dengan CAR menunjukkan bahwa semakin tinggi kecukupan modal maka akan meningkatkan profitabilitas perusahaan. Hal ini menunjukkan bahwa kecukupan modal berpengaruh positif terhadap profitabilitas. Hasil penelitian ini sejalan dengan penelitian yang dilakukan oleh Mubarok (2010) yang menunjukkan bahwa kecukupan modal berpengaruh positif terhadap profitabilitas bank.

Hipotesis pertama dalam penelitian ini menyatakan bahwa risiko kredit memperlemah pengaruh kecukupan modal pada profitabilitas. Hasil pengujian dengan menggunakan MRA menunjukkan adanya hubungan yang tidak searah atau berlawanan karena memiliki nilai koefisien yang berbeda, sehingga dapat disimpulkan bahwa variabel Risiko kredit (NPL) merupakan variabel moderasi yang memperlemah pengaruh kecukupan modal (CAR) pada Profitabilitas.

Menurut Dewi dan Budiasih (2016) akibat tingginya NPL, perbankan harus menyediakan pencadangan yang lebih besar, sehingga modal bank juga akan ikut terkikis. Hal ini sesuai dengan Pecking Order Theory yang menyatakan bahwa perusahaan akan mengutamakan pendanaan dari dalam perusahaan (internal financing) lebih dulu dari sumber pendanaan dari luar perusahaan (external financing).

Tingkat risiko kredit yang tinggi akan mengakibatkan semakin berkurangnya dana atau modal yang dihimpun sehingga dapat menurunkan 
kemampuan bank dalam menyalurkan kredit. Hal ini dapat mengakibatkan turunnya kepercayaan nasabah yang dapat menurunkan profitabilitas. Hasil penelitian ini didukung oleh penelitian yang dilakukan Utomo (2008) dan Suardita (2015) yang menunjukkan bahwa risiko kredit memperlemah pengaruh kecukupan modal pada profitabilitas. Hal ini menjelaskan bahwa bank yang memiliki tingkat kecukupan modal yang tinggi namun jika memiliki tingkat risiko kredit yang tinggi akan menurunkan tingkat profitabilitas bank.

Hasil pengujian dengan menggunakan Moderated Regression Analysis (MRA) menunjukkan bahwa koefisien regresi penyaluran kredit yang diproksikan dengan LDR menunjukkan bahwa semakin tinggi penyaluran kredit maka akan meningkatkan profitabilitas perusahaan. Hal ini menunjukkan bahwa penyaluran kredit berpengaruh positif terhadap profitabilitas. Hasil penelitian ini sejalan dengan penelitian yang dilakukan oleh Alhaq, dkk. (2012), Septiarini dan Ramantha (2014) dan Indrayani, dkk. (2016) yang menunjukkan bahwa penyaluran kredit berpengaruh positif terhadap profitabilitas.

Hipotesis kedua dalam penelitian ini menyatakan bahwa risiko kredit memperlemah pengaruh penyaluran kredit pada profitabilitas. Hasil pengujian dengan menggunakan MRA menunjukkan bahwa koefisien regresi variabel interaksi antara variabel penyaluran kredit dengan variabel risiko kredit menunjukkan nilai koefisien yang berbeda sehingga menunjukkan adanya hubungan yang tidak searah atau berlawanan, maka dapat disimpulkan bahwa variabel Risiko kredit (NPL) merupakan variabel moderasi yang memperlemah pengaruh penyaluran kredit (LDR) pada Profitabilitas. 
Menurut Sentausa (2009) Tingkat risiko kredit yang tinggi akan menjadi salah satu penyebab sulitnya perbankan dalam menyalurkan kredit. Risiko kredit yang tinggi akan menyebabkan bank mengurangi penyaluran kredit, hal ini dikarenakan dana yang telah disalurkan tidak kembali. Sesuai dengan Teori Abstinence menyatakan bahwa dalam dunia perbankan, kredit yang diberikan oleh pihak bank kepada masyarakat tentunya akan menghasilkan pendapatan bunga yang akan mempengaruhi jumlah laba suatu perusahaan perbankan. Jika bank tidak optimal menyalurkan dana dalam bentuk kredit maka pendapatan bunga yang seharusnya diterima menjadi berkurang (Trisna, 2017).

Risiko kredit yang tinggi akan menyebabkan penurunan penyaluran kredit, hal ini akan menyebabkan berkurangnya bunga yang seharusnya diterima sehingga tingkat profitabilitas akan menurun. Kelancaran pengembalian kredit oleh nasabah menjadi tolak ukur bahwa bank dapat mengelola dana dengan baik. Hasil penelitian ini didukung oleh penelitian yang dilakukan oleh Oktaviani dan Yusuf (2014) serta Dewi (2018) yang menunjukkan bahwa risiko kredit memperlemah pengaruh penyaluran kredit pada profitabilitas. Hal ini menjelaskan bahwa bank yang memiliki tingkat penyaluran kredit yang tinggi namun jika memiliki tingkat risiko kredit yang tinggi akan menurunkan tingkat profitabilitas bank.

Penelitian ini membuktikan bahwa risiko kredit memperlemah pengaruh kecukupan modal dan penyaluran kredit pada profitabilitas bank. Hasil penelitian ini sesuai dengan Pecking Order Theory yang menyatakan bahwa perusahaan akan mengutamakan pendanaan dari dalam perusahaan (internal financing) lebih 
dulu dari sumber pendanaan dari luar perusahaan (external financing). Sejalan dengan Teori Abstinence yang menyatakan bahwa dalam dunia perbankan, kredit yang diberikan oleh pihak bank kepada masyarakat tentunya akan menghasilkan pendapatan bunga yang akan mempengaruhi jumlah laba yang akan berpengaruh pada tingkat profitabilitas.

Hasil penelitian ini memberikan hasil uji diperoleh besarnya adjusted $\mathrm{R}^{2}$ adalah sebesar 0,78 yang berarti variabel independen dalam penelitian ini mempengaruhi variabel dependen sebesar 78 persen dan sisanya sebesar 22 persen dipengaruhi oleh faktor lain sehingga terdapat variabel lain yang berpengaruh namun tidak ada dalam penelitian ini. Sehingga peneliti selanjutnya dapat menggunakan variabel lain yang berpengaruh serta memperluas sampel penelitian dan data penelitian. Misalnya dengan menggunakan periode pengamatan yang lebih panjang agar hasil lebih akurat

Hasil penelitian ini dapat menjadi referensi, tambahan informasi dan bahan pertimbangan dalam pengambilan keputusan bagi pihak yang berkepentingan di dalam maupun luar perusahaan dengan melihat kecukupan modal dan penyaluran kredit. Risiko kredit pada bank juga harus ditelaah kembali oleh pihak yang berkepentingan karena salah satu fungsi bank adalah menyalurkan kredit kepada masyarakat yang tentunya tidak akan terlepas dari risiko kredit itu sendiri. Perusahaan perbankan sebaiknya selalu meminimalkan risiko kredit yang dimilikinya dengan meningkatkan pengawasan pemberian kredit agar tingkat risiko kredit berada dibawah batas maksimum yaitu 5 persen sesuai dengan 
standar yang ditetapkan oleh Bank Indonesia, sehingga dapat mempertahankan atau meningkatkan tingkat profitabilitas bank.

\section{SIMPULAN}

Berdasarkan hasil analisis dan pembahasan yang telah dilakukan, maka dapat disimpulkan bahwa risiko kredit mampu memoderasi pengaruh kecukupan modal pada profitabilitas Bank Umum Swasta Nasional (BUSN) Devisa periode 20132017. Hal ini menjelaskan bahwa bank yang memiliki tingkat kecukupan modal yang tinggi namun jika memiliki tingkat risiko kredit yang tinggi akan menurunkan tingkat profitabilitas bank.

Risiko kredit mampu memoderasi pengaruh penyaluran kredit pada profitabilitas Bank Umum Swasta Nasional (BUSN) Devisa periode 2013-2017. Hal ini menjelaskan bahwa bank yang memiliki tingkat penyaluran kredit yang tinggi namun jika memiliki tingkat risiko kredit yang tinggi akan menurunkan tingkat profitabilitas bank.

Perusahaan yang terdaftar dalam sektor perbankan di Bursa Efek Indonesia sebaiknya selalu meminimalkan risiko kredit yang dimilikinya dengan meningkatkan pengawasan pemberian kredit agar tingkat risiko kredit berada dibawah batas maksimum yaitu 5 persen sesuai dengan standar yang ditetapkan oleh Bank Indonesia, sehingga dapat mempertahankan atau meningkatkan tingkat profitabilitas bank. 
Para pihak yang berkepentingan diharapkan mampu memperhatikan nilai kecukupan modal, penyaluran kredit dan risiko kredit sebagai bahan pertimbangan dalam pengambilan keputusan.

Penelitian selanjutnya diharapkan mampu memperluas sampel penelitian dan data penelitian. Misalnya dengan menggunakan periode pengamatan yang lebih panjang agar hasil lebih akurat atau menambahkan variabel lain yang berpengaruh namun tidak ada dalam penelitian ini, dikarenakan hasil uji memberikan hasil dimana diperoleh besarnya adjusted $\mathrm{R}^{2}$ adalah sebesar 0,78 yang berarti variabel independen dalam penelitian ini mempengaruhi variabel dependen sebesar 78 persen dan sisanya sebesar 22 persen dipengaruhi oleh faktor lain sehingga terdapat variabel lain yang berpengaruh namun tidak ada dalam penelitian ini.

\section{REFERENSI}

Alhaq, M., Taufik, D. T.(2012). Pengaruh Capital Adequacy Ratio, Kualitas Aktiva Produktif, Non Performing Loan dan Loan to Deposit Ratio Terhadap Profitabilitas Perusahaan Perbankan yang Terdaftar di Bursa Efek Indonesia Periode 2008-2010. Skripsi. Fakultas Ekonomi Universitas Riau.

Ali, A., Sabir, D. H. M., \& Taqi, M. (2014). Do Non Performing Loan Affect Bank Performance? Evidence from Banks at Karachi Stock Exchange (KSE) of Pakistan. International Journal of Research in Social Sciences, 4(1), 363.

Agustiningrum, R. (2013). Analisis Pengaruh CAR, NPL dan LDR Terhadap Profitabilitas Pada Perusahaan Perbankan. E-Jurnal ManajemenUniversitas Udayana, 2(8).

Dendawijaya, L. (2009). Manajemen Perbankan. Jakarta: Penerbit Ghalia Indonesia. 
Dewi, N. P. E. N., \&Budiasih, I G. A. N. (2016). Kualitas Kredit Sebagai Pemoderasi Pengaruh Tingkat Penyaluran Kredit Dan BOPO Pada Profitabilitas. E-Jurnal Akuntansi Universitas Udayana, 15(1), 784798.

Dewi, N. L. P. S. R., \& Ratnadi, N. M. D. (2018). Pengaruh Jumlah Nasabah Kredit dan Kredit yang Disalurkan pada Profitabilitas dengan NPL Sebagai Pemoderasi. E-Jurnal Akuntansi Universitas Udayana.22(2), 1335-1362.

Haneef, S., Riaz, T., Ramzan, M., Mansoor, A. R., Hafiz, M., Ishaq., \& Yasir, K. (2012). Impact of Risk Management on Non Performing Loans and Profitability of Banking Sector of Pakistan. International Journal of Bussiness and Social Science,3(7), 307-315.

Hantono. (2017). Effect of Capital Adequacy Ratio (CAR), Loan to Deposit Ratio (LDR) and Non Performing Loan (NPL) to Return On Assets (ROA) Listed in Banking in Indonesia Stock Exchange. International Journal of Education and Research Faculty of Economic University Prima Indonesia, 5(1), 69-80.

Honora, R., Makhdalena., \&Riadi, RM. (2017). Pengaruh CAMEL Terhadap Return Saham yang Terdaftar Pada Bank Umum Swasta Nasional Pada BEI Periode 2012-2014. Jurnal Online Mahasiswa Universitas Riau, 4(2).

Indrayani, P. A., Yudiaatmaja, F., \& Suwendra, I. W. (2016). Pengaruh Non Perfoming Loan (NPL), Loan To Deposit Ratio (LDR) Dan Net Interest Margin (NIM) Terhadap Return on Asset (ROA) Pada Bank Umum Yang Terdaftar Di Bursa Efek Indonesia Tahun 2014. E-Journal Bisma UniversitasPendidikan Ganesha Jurusan Manajemen,4(1), 28-47.

Kalopo, T., Funso, Kolade, Ayeni R., \& Ojo, O. M., (2012). Credit Risk and Commercial Bank Performance in Nigeria: A Panel Model Approach. Australian Journal of Bussiness Management Research,2(2), 31-38.

Mubarok, M. H. (2010). Pengaruh Non Performing Loan, Capital Adequacy Ratio, Loan to Deposit Ratio Terhadap Profitabilitas di Sektor Perbankan yang Go Publik di Bursa Efek Indonesia. Skripsi. Fakultas Ekonomi Universitas Pembangunan Nasional.

Myrna, R. B. (2013). The Relationship Between Bank Credit Risk and Profitability and Liquidity. The International Journal of Business and Finance Research, 7(3). 
Negara, I.P.A.A., \&Sujana, I. K.(2014). Pengaruh Capital Adequacy Ratio, Penyaluran Kredit dan Non Performing Loan Pada Profitabilitas. EJurnal Akuntansi. Fakultas Ekonomi dan Bisnis Universitas Udayana, 9(2), 325-339.

Nusantara, A. B. (2009). Analisis Pengaruh NPL, CAR, LDR, dan BOPO Terhadap Profitabilitas Bank (Perbandingan Bank Umum Go Publik dan bank Umum Non Go Publik di Indonesia Periode 2005-2007). Tesis. Program Studi Magister Manajemen, universitas Diponegoro, Semarang.

Oktaviani, A., \& Yusuf, M. (2014). Pengaruh Jumlah Kredit yang Disalurkan Terhadap Profitabilitas Perbankan dengan Moderasi Resiko Kredit. Jurnal Manajemen dan Akuntansi PRESTASI. 13(2).

Purba, A. G., \& Damayanthi, I. G. A. E. (2018). Pengaruh Kecukupan Modal, Struktur Modal dan Ukuran Perusahaan Pada Profitabilitas dengan Risiko Kredit Sebagai Pemoderasi. E-Jurnal Akuntansi Universitas Udayana, 23(2),1008-1037.

Putra, I. D. G. A., \& Suardikha, I. M. S. (2016). Kemampuan Struktur Finansial, Pertumbuhan Nasabah, dan Loan to Deposit Ratio Sebagai Predikator Rentabilitas Lembaga Perkreditan Desa. E-Jurnal Akuntansi UniversitasUdayana,14(1), 253-283.

Riaz, S. (2013). Profitability Determinants of Commercial Bank in Pakistan. Proceeding of 6 th International Bussines and Social Sciences Research Conference.

Riyadi, S. (2015). Banking Assets And Liability Management. Jakarta: Lembaga Penerbit Fakultas Ekonomi Universitas Indonesia.

Septiarini, N. L. S., \& Ramantha, I. W. (2014). Pengararuh Rasio Kecukupan Modal dan Rasio Penyaluran Kredit Terhadap Profitabilitas Dengan Moderasi Rasio Kredit Bermasalah. E-Jurnal Akuntansi UniversitasUdayana, 7(1), 192-206.

Suardita, I. W., \&Putri, I. G. A. M. A.(2015). Pengaruh Kecukupan Modal Dan Penyaluran Kredit Pada Profitabilitas Dengan Pemoderasi Risiko Kredit. E-Jurnal Akuntansi Universitas Udayana, 11(2), 426-440.

Suhardjono, Mudrajad Kuncoro. (2002). Manajemen Perbankan Teori danAplikasi. Penerbit BPFE. Jakarta. 
Tracey, M. (2011). The Impact of Non Performing Loan on Loan Growth : An Econometric Case Study of Jamaica and Trinidad and Tobago. Caribbean Centre for Money and Finance Paper.

Trisna, A. A. A., \& Budiartha, I. K. (2017). Kualitas Kredit Sebagai Pemoderasi Pengaruh Tingkat Penyaluran Kredit dan Dana Pihak Ketiga Pada Profitabilitas. E-Jurnal Akuntansi Universitas Udayana.19(3), 2090-2117

Utomo, A. P. (2008). Pengaruh Non Performing Loan Terhadap Kinerja Keuangan pada PT. Bank Mandiri (Persero), Tbk. Tesis. Program Pasca Sarjana Universitas Guna Darma Jakarta.

Warnayanti, K. A., \& Dewi, S. K. S. (2018). Peran Risiko Kredit Dalam Memoderasi Pengaruh Kecukupan Modal, Penyaluran Kredit Dan Bopo Terhadap Profitabilitas. E-Jurnal Manajemen Universitas Udayana, 7(1), 105-133.

Wiagustini, N. L. P. (2010). Dasar-Dasar Manajemen Keuangan. Cetakan Pertama. Bali: Udayana University Press.

Wibisono, K. (2013). Analisis Pengaruh CAR, NPL, NIM dan LDR Terhadap ROA Pada Bank Umum Swasta Nasional di Indonesia. Jurnal EkonomiDaerah, 1(1). 